\title{
HAEMOLYTIC EFFECTS OF SAMANEA SAMAN (JACQ.), TECTONA GRANDIS (L.) AND DIPTEROCARPUS TURBINATUS (GAERTN) SEED EXTRACTS ON SINGHI FISH, HETEROPNEUSTES FOSSILIS (BLOCH)
}

\author{
MUNIRA NASIRUDDIN ${ }^{1}$, MOHAMMAD ALI AZADI AND SHABNAM CHOWDHURY \\ Department of Zoology, University of Chittagong, Chittagong-4331, Bangladesh
}

\begin{abstract}
The haemolytic effects of distilled water, 50\% ethyl alcohol and 100\% ethyl alcohol extracts of three plant seeds, Fulkoroi (Samanea saman), shegoon (Tectona grandis) and Gargan (Dipterocarpus turbinatus) were studied on a predatory fish Heteropneustes fossilis under laboratoary conditions. Comparative data of control and treated fishes showed that the toxic components induced changes in the blood parameters. Piscicides inducing toxicity were evident from decreased RBC counts, low haemoglobin percentage and decreased PCV, MCV, MCH values but increased WBC counts. Haemolysis included shrunken or swollen RBC, granulated nuclei of RBC and pyknotic and swollen nuclei of WBC, cellular damage resulting in bare nuclei of RBC and WBC, clumping of RBC and syncitium of RBC matrix. Damage of blood cells with $100 \%$ ethyl alcohol extract was pronounced with all the seed extracts. The order of toxicity on the blood parameters statistically were $T$. grandis $>S$. saman $>D$. turbinatus seed extracts. On the basis of haemolysis of blood cell the effects were $D$. turbinatus $>S$. saman $>T$. grandis seed extracts.
\end{abstract}

Key words: Haemolytic effects, Bloo parameters, Samanea saman, Tectona grandis, Dipterocarpus turbinatus, Seed extracts, Heteropneustes fossilis.

\section{Introduction}

The haematological assessment is the rising motive to prove any disturbance of environmental influences on fishes. Study of haematological parameters on the toxic extracts of the blood parameters of fishes is an important basic effort which leads to understand the impact of the piscicides on fishes. Haematological parameters are related to the response of the organisms to changing environmental conditions. These parameters of a fish reflect the ecological conditions of its habitat. Blood parameters are probably one of the rapid and detectable variations under stress. Any deviation from the normal values may be due to the alterations in the physiological and pathological states of the fish (Blaxhall 1972, Smith et al. 1979). The effect of toxicants on fish can be assessed by the use of haematological indices as it has been reported to be a routine procedure in toxicological research, environmental monitoring and fish health conditions. The changes

\footnotetext{
${ }^{1}$ Corresponding author : Email: maazadi@yahoo.com
} 
in the characteristics of blood cells are important diagnostic indicators of environmental stress on fish (Blaxhall 1972). These changes can provide evidence of exposure to toxicants (Lester and Budd 1979, Dick and Dixon 1985).

A number of studies has been carried out on the effects of plant pisicicidal compounds on fish haematology at home and abroad. Effect of sub lethal concentrations of Parkia biglobosa on haematological parameters of the African catfish, Clarias gariepinus has been reported by Fafioye and Adebisi (2000). Agbon et al. (2002) studied on the acute toxicity of tobacco (Nicotiana tobacum) leaf dust on Oreochromis niloticus and haematological changes resulting from sublethal exposure. Adeyemo (2005) observed the haematological and histopathological effects of Cassava mill effluent in Clarias gariepinus. Haematological and piscicidal effects of Carica papaya seeds on catfish, Clarias gariepinus were studied by Ayotunde et al. (2011). At home, haemolytic effects of Cassia siamea, Datura metel, Cassia tora and Albizzia lebbeck seed extracts on Heteropneustes fossilis and Channa punctatus were studied by Nasiruddin et al. (2001, 2002). Nasiruddin et al. (2010) also studied the haemolytic effects of six plant seed extracts on $H$. fossilis whilst haematological changes in the blood parameters and blood cells of $H$. fossilis treated with Tabarnaemontana divaricata plant part extracts were studied recently (Nasiruddin et al. 2011).

It is desirable to evaluate the haematological changes in the blood parameters and blood cells of $H$. fossilis (Bloch) resulting from the toxic effects of the extracts of plant seeds of indigenous plants S. saman (Jacq.), T. grandis (L.), and D. turbinatus (Gaertn). The present work thus deals with the differential cell counts of the RBC, WBC and determination of haemoglobin content of $\mathrm{H}$. fossilis. From the reading, the packed cell volume (PCV), mean corpuscular volume (MCV) and mean corpuscular hemoglobin $(\mathrm{MCH})$ were calculated. The present study would provide a baseline data on the effect of the plant seed extracts on some haematological parameters and blood cells of the fish.

\section{Materials and Methods}

Seeds of Samanea saman, Tectona grandis and Dipterocarpus turbinatus locally called 'Fulkoroi', 'Shegoon' and 'Garjan' respectively were collected from Chittagong University campus. Seeds were collected from ripe fruits and pods, dried and preserved in separate air tight glass jars in the laboratory.

In order to extract the toxicant, well dried seeds were grinded at first in a mortar, and then in an electric blender and sieved through a $0.0025 \mathrm{~cm}^{2}$ sieve. Ten grams of the grinded powder were dissolved with $100 \mathrm{ml}$ of distilled water, $50 \%$ ethyl alcohol or $100 \%$ ethyl alcohol separately and thoroughly mixed by a magnetic stirrer. The resultant liquid was filtered through fine cloth to make up the stock solution. The five test concentrations $(\mathrm{ppm})$ were calculated from this stock solution by appropriate dilution (APHA 1976). Healthy live fishes were collected from the local fish market of Chittagong city. The 
fishes were maintained in a glass aquarium $(60 \times 30 \times 30 \mathrm{~cm})$ containing tap water and acclimatized for 3-4 hours in laboratory condition. The average total length of $H$. fossilis was $10.82 \pm 0.96 \mathrm{~cm}$ and weight was $9.12 \pm 0.57 \mathrm{~g}$ respectively.

Blood films of both control and treated fishes (middle dose of each experiment) were collected by cardiac puncture with the aid of needle, taken on clean greaseless slides, smeared, air dried and stained in Leishmans stain, to observe the changes of blood cells. Blood was drawn in RBC and WBC pipettes with a haemocytometer to count the RBC and WBC. Blood was also collected in a haemometer to measure the haemoglobin content. Total number of RBC and WBC were estimated using the method of Raphael (1983). Haemoglobin was measured with Sahli's haemometer. The absolute blood parameters i.e. packed cell volume (PCV), mean corpuscular volume (MCV) and mean corpuscular hemoglobin (MCH) were evaluated following Bhatt and Farswan (1992).

The " $t$ " test was applied to determine level of significance of statistical analysis made between the values of normal versus treated blood parameters of each of the plant seed extracts. Microphotographs were taken with a compound microscope (Microcos- Austria MC- 100 microscope) having photographic attachment (Canon Power Shot A-640 camera, Japan) under x1000 magnification.

\section{Results and Discussion}

Haemolytic effects of S. saman, T. grandis and D. turbinatus seed extracts on the blood parameters of $\boldsymbol{H}$. fossilis: The comparative analysis of the haematological data for the experimental and control fishes is given in Tables 1 and 2. The present investigation was done only with the fishes of the mid-dose. Exposure to different extracts of S. saman, $T$. grandis and D. turbinatus seeds produced decrease in $\mathrm{RBC}$, haemoglobin content $(\mathrm{Hb} \mathrm{g}$ and \%), PCV, MCV, MCH, except WBC the number of which increased (Table 1). Comparative data of the haematological parameters of control and treated fishes showed that the toxic property of the plant seed extracts induced significant changes in the blood parameters of $H$. fossilis. The RBC counts, haemoglobin contents, $\mathrm{PCV}, \mathrm{MCV}$ and $\mathrm{MCH}$ values of blood of treated fishes decreased and the WBC counts increased with all the experimental seed extracts. Generally all the blood parameters of the experimental fishes were reduced serially in the three extracts which were proved by " $t$ " test (Table 2). The test applied to determine the level of significance of statistical analysis made between the blood parameters of normal versus treated fishes indicated that these three plant seed toxicants had definitely haemolytic properties.

The order of calculation of the affectivity of the solvents was control < distilled water < $50 \%$ ethyl alcohol $<100 \%$ ethyl alcohol. The " $\mathrm{t}$ " test showed significant $(\mathrm{P}<0.05)$ decrease in values of all the haematological parameters with all the three plant seed extracts of S. saman, T. grandis and D. turbinatus. However, the WBC values in all the three seed extract, $\mathrm{Hb}(\mathrm{g})$ value, $\mathrm{PCV}, \mathrm{MCV}$ and $\mathrm{MCH}$ values of distilled water and 
MCH values of 50\% ethyl alcohol extracts of S. saman seeds, PCV and MCV values of distilled water and $\mathrm{MCH}$ values of $50 \%$ ethyl alcohol extracts of $T$. grandis seeds, RBC, $\mathrm{Hb}(\%$ and $\mathrm{g}$ ), PCV, MCV and $\mathrm{MCH}$ values of distilled water and $\mathrm{MCH}$ values of $50 \%$ ethyl alcohol extracts did not show significant variation from the control group. With all the three seed extracts variation were in the order of control < distilled water extract < $50 \%$ ethyl alcohol extract $<100 \%$ ethyl alcohol extract. Trend of toxicity on the basis of the blood parameters of the three seeds, was in the order: T. grandis $>S$. saman $>D$. turbinatus seeds (with respect to t' test).

Table 1. RBC, WBC, Hb, PCV, MCV and MCH of control and treated individuals of $H$. fossilis treated with $S$. saman, $T$. grandis and $D$. turbinatus seed extracts (Values are expressed as mean $\pm \mathrm{SE}$ ).

\begin{tabular}{|c|c|c|c|c|c|c|c|c|}
\hline \multirow[t]{2}{*}{ Seed } & \multirow[t]{2}{*}{ Treatment } & \multirow{2}{*}{$\begin{array}{c}\mathrm{RBC} \\
\left(\mathrm{x} 10^{6} / \mathrm{mm}^{3}\right)\end{array}$} & \multirow{2}{*}{$\begin{array}{c}\text { WBC } \\
\left(\mathrm{x} 10^{3} / \mathrm{mm}^{3}\right)\end{array}$} & \multicolumn{2}{|c|}{$\mathrm{Hb}$} & \multirow{2}{*}{$\begin{array}{l}\text { PCV } \\
(\mathrm{g} / \mathrm{dl})\end{array}$} & \multirow{2}{*}{$\begin{array}{c}\mathrm{MCV} \\
\left(\mu \mathrm{m} / \mathrm{m}^{3}\right)\end{array}$} & \multirow{2}{*}{$\begin{array}{l}\text { MCH } \\
(\mu / \mathrm{mg})\end{array}$} \\
\hline & & & & $\%$ & $(\mathrm{~g} / \mathrm{dl})$ & & & \\
\hline \multirow{7}{*}{ S. saman } & Control & 6.05 & 3.57 & 80.00 & 12.28 & 36.84 & 74.43 & 132.31 \\
\hline & & & & & & & & \\
\hline & $\begin{array}{l}\text { Distilled } \\
\text { water }\end{array}$ & $\begin{array}{c}5.8 / \\
\pm 0.03\end{array}$ & $\begin{array}{c}4.49 \\
\pm 0.07\end{array}$ & $\begin{array}{l}69.20 \\
\pm 1.11\end{array}$ & $\begin{array}{l}10.60 \\
\pm 0.34\end{array}$ & $\begin{array}{l}31.80 \\
\pm 1.00\end{array}$ & $\begin{array}{l}65.50 \\
+1.20\end{array}$ & $\begin{array}{r}11 / .82 \\
+2.17\end{array}$ \\
\hline & $50 \%$ ethyl & 4.42 & 5.27 & 51.20 & 7.20 & 21.60 & 61.72 & 115.78 \\
\hline & alcohol & \pm 0.02 & \pm 0.07 & \pm 1.59 & \pm 0.29 & \pm 0.80 & \pm 0.19 & \pm 3.64 \\
\hline & $100 \%$ ethyl & 3.87 & 6.16 & 42.00 & 5.40 & 16.20 & 49.62 & 108.31 \\
\hline & alcohol & \pm 0.02 & \pm 0.04 & \pm 0.85 & \pm 0.16 & \pm 0.51 & \pm 2.41 & \pm 2.32 \\
\hline \multirow{8}{*}{ T. grandis } & & 6.29 & 3.88 & 70.40 & 10.92 & 31.52 & 52.10 & 146.25 \\
\hline & Control & \pm 0.02 & \pm 0.01 & \pm 1.46 & \pm 0.31 & \pm 1.18 & \pm 1.64 & \pm 4.98 \\
\hline & Distilled & 5.77 & 4.21 & 58.60 & 8.72 & 26.16 & 45.36 & 110.74 \\
\hline & water & \pm 0.08 & \pm 0.06 & \pm 1.08 & \pm 0.26 & \pm 0.65 & \pm 1.20 & \pm 5.85 \\
\hline & $50 \%$ ethyl & 4.19 & 4.98 & 42.40 & 7.28 & 21.84 & 42.35 & 101.90 \\
\hline & alcohol & \pm 0.02 & \pm 0.02 & \pm 3.10 & \pm 0.49 & \pm 1.47 & \pm 0.85 & \pm 8.83 \\
\hline & $100 \%$ ethyl & 3.49 & 5.42 & 35.60 & 4.72 & 13.16 & 37.55 & 100.12 \\
\hline & alcohol & \pm 0.02 & \pm 0.04 & \pm 1.08 & \pm 0.22 & \pm 0.65 & \pm 1.88 & \pm 7.43 \\
\hline \multirow{8}{*}{$\begin{array}{c}D . \\
\text { turbinatus }\end{array}$} & Control & 5.94 & 3.40 & 68.00 & 10.52 & 31.56 & 64.69 & 146.83 \\
\hline & Con & \pm 0.02 & \pm 0.02 & \pm 1.72 & \pm 0.38 & \pm 1.13 & \pm 2.04 & \pm 6.43 \\
\hline & Distilled & 4.92 & 4.39 & 64.00 & 08.52 & 26.16 & 58.76 & 110.74 \\
\hline & water & \pm 0.38 & \pm 0.03 & \pm 1.87 & \pm 0.24 & \pm 0.65 & \pm 3.65 & \pm 5.85 \\
\hline & $50 \%$ ethyl & 3.80 & 5.57 & 52.08 & 07.18 & 21.88 & 47.02 & 106.26 \\
\hline & alcohol & \pm 0.22 & \pm 0.04 & \pm 1.19 & \pm 0.07 & \pm 0.69 & \pm 3.09 & \pm 9.44 \\
\hline & $100 \%$ ethyl & 2.82 & 5.88 & 42.04 & 04.85 & 16.08 & 43.31 & 100.12 \\
\hline & alcohol & \pm 0.02 & \pm 0.04 & \pm 1.21 & \pm 0.21 & \pm 1.12 & \pm 1.75 & \pm 7.43 \\
\hline
\end{tabular}

A decrease in the number of erythrocytes and increasing number of leucocytes was observed in $H$. fossilis toxicated with lethal and sub lethal concentrations of distilled water, $50 \%$ ethyl alcohol and $100 \%$ ethyl alcohol extracts of S. saman, T. grandis and D. turbinatus seeds. These findings support the view of Dhannekar et al. (1985), Bhatt and Farswan (1992), Hymavathi and Rao (2000) and Nasiruddin et al. (2011) who reported 
similar decrease in all blood parameters except WBC. The reduction in these blood parameters is an indication of anemia caused by exposure to the plant seed extracts.

Table 2. Result of " $t$ " test between control and $S$. saman, T. grandis, D. turbinatus seed extract treated blood parameters of $H$. fossilis (P-values indicate significance at 0.01 level).

\begin{tabular}{|c|c|c|c|c|c|c|c|c|}
\hline \multirow[t]{2}{*}{ Seed } & \multirow{2}{*}{ Treatment } & \multirow{2}{*}{$\mathrm{RBC}$} & \multirow{2}{*}{ WBC } & \multicolumn{2}{|c|}{$\mathrm{Hb}$} & \multirow{2}{*}{ PCV } & \multirow{2}{*}{$\mathrm{MCV}$} & \multirow{2}{*}{$\mathrm{MCH}$} \\
\hline & & & & $\%$ & $\mathrm{~g}$ & & & \\
\hline \multirow{9}{*}{ S. saman } & Control & & & & & & & \\
\hline & vs. & 5.38 & -10.60 & 5.73 & 4.35 & 4.36 & 4.57 & 4.42 \\
\hline & $\begin{array}{l}\text { distilled } \\
\text { water }\end{array}$ & $\mathrm{P}<0.01$ & $\mathrm{P}>0.01$ & $\mathrm{P}<0.01$ & $\mathrm{P}>0.01$ & $\mathrm{P}>0.01$ & $P>0.01$ & $\mathrm{P}>0.01$ \\
\hline & Control & & & & & & & \\
\hline & vs. & 19.57 & -20.00 & 13.10 & 14.50 & 14.26 & 8.64 & 3.77 \\
\hline & $\begin{array}{c}50 \% \text { ethyl } \\
\text { alcohol }\end{array}$ & $\mathrm{P}<0.01$ & $\mathrm{P}>0.01$ & $\mathrm{P}<0.01$ & $\mathrm{P}<0.01$ & $\mathrm{P}<0.01$ & $\mathrm{P}<0.01$ & $\mathrm{P}>0.01$ \\
\hline & Control & & & & & & & \\
\hline & vs. & 103.61 & -35.97 & 21.79 & 27.41 & 26.81 & 8.81 & 7.12 \\
\hline & $\begin{array}{c}100 \% \text { ethyl } \\
\text { alcohol }\end{array}$ & $\mathrm{P}<0.01$ & $\mathrm{P}>0.01$ & $\mathrm{P}<0.01$ & $\mathrm{P}<0.01$ & $\mathrm{P}<0.01$ & $\mathrm{P}<0.01$ & $\mathrm{P}<0.01$ \\
\hline \multirow{9}{*}{ T. grandis } & Control & 06.67 & -5.89 & 6.40 & 5.43 & 3.98 & 3.23 & 4.62 \\
\hline & $\begin{array}{l}\text { vs. } \\
\text { dictilled }\end{array}$ & $\mathrm{P}<0.01$ & $\mathrm{P}>0.01$ & $\mathrm{P}<0.01$ & $\mathrm{P}<0.01$ & $\mathrm{P}>0.01$ & $\mathrm{P}>0.01$ & $\mathrm{P}<0.01$ \\
\hline & $\begin{array}{l}\text { distilled } \\
\text { water }\end{array}$ & & & & & & & \\
\hline & Control & & & & & & & \\
\hline & vs. & 75.00 & -50.00 & 7.97 & 6.27 & 5.14 & 5.20 & 4.38 \\
\hline & $\begin{array}{c}50 \% \text { ethyl } \\
\text { alcohol }\end{array}$ & $\mathrm{P}<0.01$ & $\mathrm{P}>0.01$ & $\mathrm{P}<0.01$ & $\mathrm{P}<0.01$ & $\mathrm{P}<0.01$ & $\mathrm{P}<0.01$ & $\mathrm{P}>0.01$ \\
\hline & Control & & & & & & & \\
\hline & vs. & 84.85 & -42.79 & 19.16 & 16.16 & 13.62 & 5.85 & 5.16 \\
\hline & $\begin{array}{c}100 \% \text { ethyl } \\
\text { alcohol }\end{array}$ & $\mathrm{P}<0.01$ & $\mathrm{P}>0.01$ & $\mathrm{P}<0.01$ & $\mathrm{P}<0.01$ & $\mathrm{P}<0.01$ & $\mathrm{P}<0.01$ & $\mathrm{P}<0.01$ \\
\hline \multirow{9}{*}{$\begin{array}{l}D . \\
\text { turbinatus }\end{array}$} & Control & 2.67 & & & & & & \\
\hline & vs. & $\mathrm{P}>0.01$ & -27.21 & 1.57 & 4.48 & 4.14 & 1.42 & 14.15 \\
\hline & $\begin{array}{l}\text { distilled } \\
\text { water }\end{array}$ & & $\mathrm{P}>0.01$ & $P>0.01$ & $\mathrm{P}>0.01$ & $\mathrm{P}>0.01$ & $\mathrm{P}>0.01$ & $\mathrm{P}>0.01$ \\
\hline & Control & & & & & & & \\
\hline & vs. & 9.22 & -69.00 & 7.61 & 8.68 & 7.30 & 4.78 & 3.55 \\
\hline & $\begin{array}{c}50 \% \text { ethyl } \\
\text { alcohol }\end{array}$ & $\mathrm{P}<0.01$ & $\mathrm{P}>0.01$ & $\mathrm{P}<0.01$ & $\mathrm{P}<0.01$ & $\mathrm{P}<0.01$ & $\mathrm{P}<0.01$ & $\mathrm{P}>0.01$ \\
\hline & Control & & & & & & & \\
\hline & vs. & 141.73 & -52.89 & 12.34 & 13.13 & 9.72 & 7.96 & 4.75 \\
\hline & $\begin{array}{c}100 \% \text { ethyl } \\
\text { alcohol }\end{array}$ & $\mathrm{P}<0.01$ & $\mathrm{P}>0.01$ & $\mathrm{P}<0.01$ & $\mathrm{P}<0.01$ & $\mathrm{P}<0.01$ & $\mathrm{P}<0.01$ & $\mathrm{P}<0.01$ \\
\hline
\end{tabular}

The anemic response could be as a result of destruction of erythrocyte or inhibition of erythrocyte production (Wintrobe 1978) or haemodilution as reported by Sampath et al. (1993). A decrease in the erythrocyte count or in the percent of haematocrit indicates its 
developing anemia (Vosyliene 1999). Analysis of erythrocyte level has shown the presence of anemia or stress polycythemia which affect the transport of oxygen to critical tissue, whereas total leucocyte counts may indicate leukemia and leucocytosis, suggesting possible immune function alteration, which is caused by the increasing number of WBC .

Blood cells of control $\boldsymbol{H}$. fossilis fish: The blood smears of control $H$. fossilis indicated that the RBC were large and oval with distinct cell wall and centrally placed small circular nucleus surrounded by a thick broad rim of non granulated cytoplasm. WBC were ovoid or spheroid shaped cells with centrally placed large sized round nucleus and distinct cell wall with clear cytoplasm. The nuclei of WBC were comparatively larger than the nuclei of RBC. In both RBC and WBC the nucleus took dark blue stain and the cytoplasm took light pink to purple color stain (Plate 1A).

Effects of S. saman seed extracts on the blood cells of $H$. fossilis fish: Both $\mathrm{RBC}$ and WBC were affected with the distilled water extract of $S$. saman seeds (Plate 1B). Clumping of blood cells was evident. RBC and WBC became deshaped with damaged cell wall. RBC were deshaped with granular and bare nuclei. Syncitium was evident to some extent. Pyknotic and bare nuclei of WBC were also found.

When the fishes were treated with 50\% ethyl alcohol extract, damage of blood cells was evident (Plate 1C), showing deshaped RBC with swollen nuclei. Syncitium occurred. Some RBC were seen with granular and bare nuclei. Cytoplasm of RBC was vacuolated. WBC were swollen with bare and pyknotic nuclei.

With $100 \%$ ethyl alcohol extract extensive clumping in the blood cells were evident. RBC were with extensively damaged cell membrane, deshaped nuclei and syncitium occurred (Plate 1D). Bare and granulated nuclei of RBC were also evident. WBC were with damaged cytoplasm, with vacuoles in the matrix. Bare and pyknotic nuclei of the WBC were also observed.

Effects of T. grandis seed extracts on the blood cells of $\boldsymbol{H}$. fossilis: With distilled water extract of $T$. grandis seeds, RBC were found with damaged cell wall, swollen and deshaped nuclei. Granulated nuclei of RBC and slight cell syncitium were also evident. Deshaped WBC were seen with bare and pyknotic nuclei (Plate 1E).

As a result of the effect of $50 \%$ ethyl alcohol extract RBC were deshaped with damaged cell wall and swollen and granulated nuclei (Plate 1F). Slight syncitium in RBC matrix was evident. WBC were with dissolved cytoplasm and with irregular and deshaped nuclei. Some WBC were found to be with damaged cell wall and with swollen and pyknotic nuclei.

Exposed to $100 \%$ ethyl alcohol extract, extensive clumpings of both RBC and WBC were evident (Plate 1G). Cell membrane of RBC disintegrated and syncitium occurred. Vacuoles in the matrix and granulated nuclei of RBC were evident. WBC were shrunken with pyknotic, bare and deshaped nuclei. 

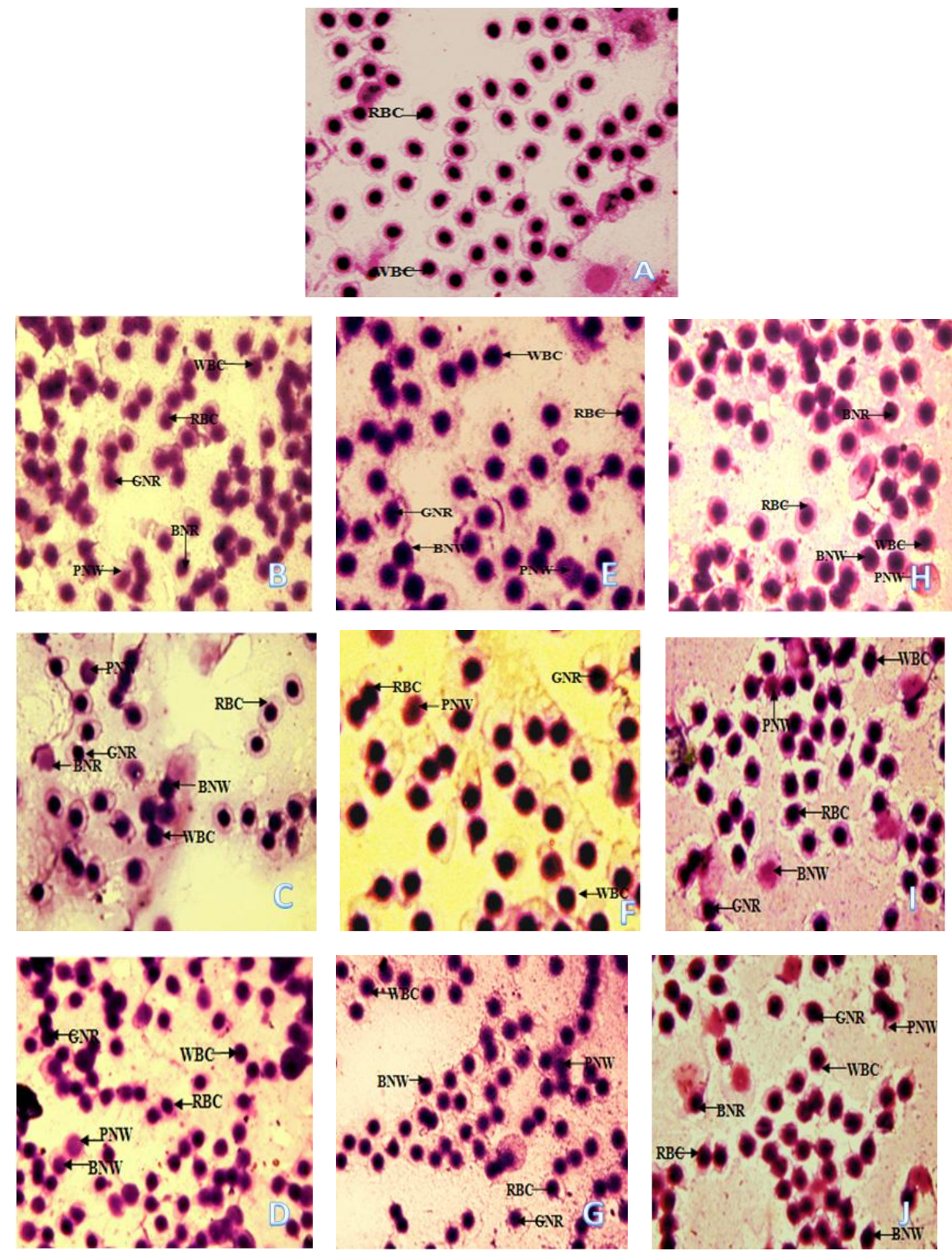

Plate 1. Microphotographs of blood cells of Heteropneustes fossilis $(\times 1000)$. (A). Control; and treated with (B). Distilled water, (C). 50\% ethyl alcohol, (D). 100\% ethyl alcohol extracts of S. saman seeds; (E). Distilled water, (F). 50\% ethyl alcohol, (G). $100 \%$ ethyl alcohol extracts of T. grandis seeds and (H). Distilled water, (I). 50\% ethyl alcohol, (J). 100\% ethyl alcohol extracts of $D$. turbinatus seeds. (BNR= bare nuclei of $\mathrm{RBC}, \mathrm{BNW}=$ bare nuclei of $\mathrm{WBC}, \mathrm{PNW}=$ pyknotic nuclei of $\mathrm{WBC}, \mathrm{GNR}=$ granular bare nuclei of $\mathrm{RBC}$ ). 
Effects of D. turbinatus seed extracts on the blood cells of $\boldsymbol{H}$. fossilis: Slightly swollen, deshaped and irregular RBC with damaged cell wall were the principal changes in the blood of $H$. fossilis exposed to distilled water extract (Plate $1 \mathrm{H} \mathrm{J}$ ). Some RBC were damaged. Granules and vacuoles were seen in the cytoplasm of RBC matrix. Some were with bare nuclei. WBC were also found with bare and pyknotic nuclei.

RBC were shrunken, deshaped and disintregrated. Cell clumping and syncitium occurred, vacuoles in some RBC cytoplasm were evident when exposed to $50 \%$ ethyl alcohol extract (Plate 1I). Granulated nuclei of RBC were also observed. WBC were with deshaped, bare and pyknotic nuclei.

The effects of $100 \%$ ethyl alcohol extract were greatly noticeable (Plate 1J). Cell membrane of RBC disintegrated hence syncitium occurred. Bare and granular nuclei of RBC were evident. Bare and pyknotic nuclei of WBC were also evident. Cytoplasm of both $\mathrm{RBC}$ and $\mathrm{WBC}$ were reduced to some extent.

Morphological changes in blood cells observed in blood smear are one of the most specific indices of toxic effect on fish. From the study of blood cell slides, the blood smear in normal fishes were without haemolysis and that of treated fishes showed haemolysis of RBC and WBC in many ways, such as changes in shape, damage of cell membrane, swollen nuclei, clumping and formation of syncitium in RBC matrix, whereas nuclei of WBC were pyknotic and bare. Similar haemolytic effects of plant toxicants were found by Bhatt and Farswan (1992), and Nasiruddin et al. (2001, 2002, 2011). In the present study, from the study of blood film damages the order of toxicity followed the pattern: D. turbinatus $>$ S. saman $>$ T. grandis seed extracts.

The toxic substances in the medium changed the haemopoitic activity. The active ingredients of the three indigenous plant seeds influenced the dynamicity of haemopoesis in $H$. fossilis. The effects on blood parameters suggested that the physiology of the fishes was disturbed to an extent resulting in the death of the fishes whilst being toxified with these plant seed extracts. On the basis of haematological studies, it would be possible to forecast the physiological state of fish.

\section{References}

Adeyemo, O. K., 2005. Haematological and histological effects of Cassava mill effluent in Calrias gariepinus. Afr. J. Biomed. Res. 8(3): 179-183.

Agbon, A. O., I. T. Omoniyi and A. A. Teko, 2002. Acute toxicity of tobacco (Nicotiana tobaccum) leaf dust on Oreochromis niloticus and haematological changes resulting from sub-lethal exposure. J. Aqua. Sci. 17: 5-8.

APHA (American Public health Association). 1976. Standard methods for the examination of water and waste water. APHA press, Washington DC. 1193 pp.

Ayotunde, E. O., B. O. Offem and A. F. Bekeh, 2011. Toxicity of Carica papaya Linn.: Haematological and piscicidal effect on catfish (Clarias gariepinus). J. Fish. Aquat. Sci. 6: 291-308.

Bhatt, J. P. and Y. S. Farswan, 1992. Haemolytic activity of piscicidal compounds of some plants to fresh water fish Barilius bendelisis (Ham.). J. Environ. Biol. 13: 333-342. 
Blaxhall, P. C., 1972. The haematological assessment of the health of freshwater fish. J. Fish. Biol. 4: 593-604.

Dhannekar, S., S. Srivastava, K. S. Rao and S. S. Pandey, 1985. Studies on toxic effect of least effective concentration of mercury on fish. A haematological study. Matsya 11: 75-78.

Dick, P. T. and D. G. Dixon, 1985. Changes in circulating blood cell levels of rainbow trout Salmo gairdneri Richardson, following acute and chronic exposure to copper. J. Fish Biol. 26: 475-481.

Fafioye, O. O. and A. A. Adebisi, 2000. Effects of sub lethal concentrations of Parkia biglobosa on haematological parameters of the African catfish, Clarias gariepinus. J. Biosci. Res. Comm. 12(4): 56-62.

Hymavathi, V. and L. M. Rao, 2000. Effect of sub lethal concentrations of Lead on the haematology and biochemical constituents of Channa punctatus. Bulletin of Pure and Applied Science. 19: 1-5.

Lester, R. G. and J. Budd, 1979. Some changes in blood cells of diseased Coho salmon. Canadian Journal of Zoology. 57: 1458-1464.

Nasiruddin, M., M. A. Azadi and F. Tabassum, 2001. Haemolytic effects of seed extracts of Cassia siamea (L.) and Datura metel (L.) on Heteropneustes fossilis (Bloch) and Channa punctatus (Bloch). Bangladesh J. Zool. 29(1): 19-28.

Nasiruddin, M., M. A. Azadi and F. A. N. Pervin, 2010. Toxicological and haemolytic effects of some plant seed extracts on Heteropneustes fossilis (Bloch). J. Asiatic Soc. Bangladesh, Sci. 36(1): 25-35.

Nasiruddin, M., M. A. Azadi, A. Jahan and R. Chowdhury, 2002. Haemolytic effects of Cassia tora (L.) and Albizzia lebbeck (L.) Benth seeds on Heteropneustes fossilis (Bloch) and Channa punctatus (Bloch). Bangladesh J. Zool. 30(1): 11-19.

Nasiruddin, M., M. A. Azadi, A. Hossain and S. I. Ara, 2011. Haematological changes in the blood parameters and blood cells of Heteropneustes fossilis (Bloch) treated with Tabarnaemontana divaricata (L.) plant part extracts. J. Asiatic Soc. Bangladesh, Sci. 37(1): 55-66.

Raphael, S. S. 1983. Lynch's Medical laboratory technola. W. B. Saunders Company, Philadelphia, London.

Sampath, K., S. Velamnial, I. J. Kennedy and R. James, 1993. Haematological changes and their recovery in Oreochromis mossambicus as function of exposure period and sub lethal levels of Ekalus. Acta Hydrobiologica 35: 73-83.

Smith, G. L., J. Hattingh and A. P. Burger, 1979. Haematological assessment of the effects of anaesthetic MS 222 in natural and neutralized form in three fresh water fish species, interspecies differences. J. Fish.Biol. 15:633-643.

Vosyliene, M. Z. 1999. The effect of heavy metal mixture on haematological parameters of rainbow trout. Heavy metals in environment. An integrated approach. Ed. D. A. Lovejoy, 295-298 pp.

Wintrobe, M. M. 1978. Clinical Haematology.Ed. H. Kimpton, London, U. K. 488 pp. 